\title{
Research on the Impact of Third-Party Certification on Green Bond Spread of the Green Industry - Considering the Effect of the Nature of Property Rights
}

\author{
Yue Hu ${ }^{1}$, Xuehua Zhang ${ }^{1, *}$, Baoan Zhang ${ }^{2}$ \\ ${ }^{1}$ School of Economics and Management, TIANGONG UNIVERSITY, Tianjin, China \\ ${ }^{2}$ University of Environmental Engineering, Hebei, China \\ *corresponding author
}

\begin{abstract}
Capital is the most basic element of production organization, and green bonds are important financing sources for the green industry. Financing costs directly affect the steady development of the green industry. In order to verify whether third-party certification can reduce the financing cost of green bonds and whether the nature of property rights has an impact on the reduction, 285 green bonds issued from 2016 to 2019 are taken as samples, and then a hierarchical multiple statistical regression analysis method is adopted to conduct a quantitative study. The results show that third-party certification, as a unique credit enhancement method for green bonds, can significantly reduce green bond spreads. In addition, it is greater that the effect on non-state-owned enterprises' green bonds is. Since bond spread is a main part of financing costs, the above means that third-party certification can reduce the financing costs of green bonds, especially for non-state-owned enterprises. In this regard, starting from reducing the cost of green bonds, the paper proposes to improve the green bond evaluation and certification standards as soon as possible, non-state-owned enterprises particularly should actively carry out third-party certification, and the government needs to further increase the implementation of third-party certification as well as strengthen multi-party cooperation.
\end{abstract}

Keywords: Financing Cost, the Nature of Property Rights, the Green Industry, Grey Relational Model

\section{Introduction}

Green development is the main theme of the development of the new era. Green cleaner production is becoming a crucial development strategy for enterprises, since enterprises can reduce pollution emissions and energy consumption by green cleaner production, in the case of producing the same number of products or offering the same quality of services as enterprise that do not have the process, and meanwhile improve enterprises' social prestige as well as competitiveness of industry. Project accomplishment is the point of the development of enterprises so that the green development of enterprise can be accelerated through enterprise's implementing green projects, such a vital method.

Green project, assessed and selected by both issuers and related institutions, refers to project or plan that can promote the sustainable development of the environment. The projects are involved in many fields mainly including mitigating and adapting to climate change, curbing the depletion of natural resources, protecting biodiversity, contamination control, etc.

Capital is the most basic factor of production and the most important element of production organization. Hence, it is of significance to improve the green financial market whether for green project implementation or green development promotion in enterprises.

Green bond is an important part of green finance. From 2015 to 2020, a series of policies such as the ISSN: 0010-8189

(c) CONVERTER 2020

www.converter-magazine.info 
Announcement on Issuing Green Financial Bonds in the Interbank Bond Market (2015) had been announced aiming to standardize and develop the green bond market. Moreover, "green channel" has been built to improve the efficiency of listing verification, promoting the development of green bonds greatly. Green bonds are increasingly significant these days when the requirements for the low-carbon development are becoming more and more urgent.

In 2016, the amount of green bond invested in green project in China added up to more than 240 billion RMB, leading to more than 11.8 million tons of $\mathrm{CO}_{2}$ emission reduction. By the end of 2020, the stock of green bonds in China had reached 813.2 billion RMB, ranking second in the world. However, compared to the conventional bond, a significantly higher financing cost of green bond (characterized by bond interest rate) owing to green bond risks hinders the further rapid development of the green bond market ${ }^{[1]}$. The green bond risks mainly arise from two aspects. One is the "greenwashing", and the other is the uncertainty of green projects.

The "greenwashing" risk springs from the financing of the non-green projects through the green channels, which pretend to be environmentally friendly. The investors' risk expectation of "greenwashing" increases when the use of green bond funds is unclear ${ }^{[2]}$. Consequently, the investment enthusiasm declines. The uncertainty risk stems from the fact that green projects are basically financing projects of strategic emerging industries with uncertainty of the development of the industrial chain ${ }^{[3]}$, policy continuity ${ }^{[4]}$, the innovation, application of technology ${ }^{[5]}[4]$, etc.

The higher green bond yield is required due to the two types of risks mentioned. The risk premium can reflect the requirement, referring to green bond spread (the difference between the green bond yield and the risk-free interest rate). Green bond spread reflects not only the return required by the investors bearing the risks, but also the financing cost for the issuers. Low-cost green bond funds spur energy-saving transformation in enterprises, which contributes to the green and low-carbon development of the industries. Determined by the laws of the industrial development, strategic emerging industries are growing with uncertainties inevitably, resulting in the uncertainty risk difficult to get rid of. Hence, the most effective way to cut down the risk premium is to enhance green bond reputation and ease the " greenwashing" risk. In theory, third-party certification, a unique credit enhancement method for green bonds, can make up for the lack of poor disclosure of usage reports of green bond funds. In this case, investors bear less "greenwashing" risk and ask for lower risk premium, contributing to less green bond issuance cost for the issuers. In addition, the nature of state-owned property rights provides implicit guarantees to entities, which can significantly reduce conventional bond spread ${ }^{[6]}$. It is worth discussing that whether green bond spread is affected by the nature of state-owned property rights, but there is no relevant research report yet.

In view of the above, we took 285 green bonds issued in China from 2016 to 2019 as samples. Then, considering third-party certification, a unique credit enhancement method for green bonds, hierarchical multiple regression analysis was adopted to verify whether third-party certification can reduce green bond spread, and to further verify whether the nature of property rights has an impact on green bond spread as well as on relationship between third-party certification and green bond spread.

\section{Research hypothesis}

\section{Hypothesis 1: third-party certification can reduce green bond spread.}

In China, green industries including energy-saving and environmental protection industry, clean energy industry, clean production industry and ecological environment industry have been growing rapidly in recent years with the uncertainty in development to some degree, such a basic characteristic of emerging industries. It leads to the requirement for higher risk premiums on green bonds, which for companies is the higher issuance premiums (the difference between the green bond interest rate and the risk-free interest rate), that is, higher financing costs. Green bond funds can support projects in many fields including equipment manufacturing, construction and operation of

ISSN: 0010-8189

(C) CONVERTER 2020

www.converter-magazine.info 
facilities and engineering, pollution prevention, ecological restoration, etc. Hence, it is inevitable that there are enterprises treacherously using rules to issue green bonds successfully, the real purpose of which, however, may not for the main environmental protection projects. It is useful for reduction in green bond risk premiums required by the investors to disclose more information about green bonds to be issued like disclosure of the use of the funds to ease the risk of "greenwashing". In this case, enterprises can obtain low-cost funds by issuing green bonds with a lower spread. Furthermore, with sufficient funds to solve the current problems, the green industry can grasp more developing opportunities.

At present, third-party certification is not mandatory for green bonds in China. There is only guidance on green bonds given by the China Securities Regulatory Commission, requiring that when enterprises apply for issuing green corporate bonds, their prospectus should disclose the type of the green industry project to be invested, the basis or standard for identification of the project, the environmental benefit targets, the usage plan and management system of the raised funds, etc. However, the requirements are frameworks, which means there are no specified provisions on the level of detail and relevant indicators of the disclosure. third-party certification and evaluation report is a supplement, explaining including which project the green bond funds are invested in and whether it is beneficial to the environment, so that with the problem of information asymmetry between issuers and investors alleviated, having access to explicit use of the funds, the investors may lower their expectations of green bond risks and requirements for risk premiums, by which issuers may cut down the issuance cost of green bonds. Based on the analysis above, the Hypothesis 1 is proposed: third-party certification can reduce green bond spread.

\section{Hypothesis 2: The nature of state-owned property rights can reduce green bond spread.}

Classified by the nature of property rights, in the capital market, there are two main types of enterprises. One is state-owned enterprises and the other is non-state-owned enterprises. And they are in different financing status ${ }^{[7]}$. State-owned enterprises have certain advantages over non-state-owned enterprises, since generally, state-owned enterprises are believed to have government credit as an invisible guarantee. Bonds issued by state-owned enterprises have invisible rigid redemption and is in a lower level of expected risk. However, without implicit guarantee of the government, non-state-owned enterprises rely on their own credit when financing. Bonds issued by non-state-owned enterprises is in a higher level of risk assessed by the public. Hence, in the same condition, state-owned enterprises bear a lower bond spread than non-state-owned enterprises. Based on the analysis above, the Hypothesis 2 is proposed: the nature of state-owned property rights can reduce green bond spread.

\section{Hypothesis 3: The nature of state-owned property rights negatively moderates the effect of third-party certification on green bond spread.}

In theory, positive reports disclosed by the issuers can ease information risks that investors take, contributing to a lower bond spread. The effect is more obvious in non-state-owned enterprises because the bond risks are expected in a higher level. It means compared to state-owned enterprises' bond spread, non-state-owned enterprises' bond spread is more sensitive to incremental information. Therefore, in non-state-owned enterprises, the effect of third-party certification, as positive incremental information, is greater. Based on the analysis above, the Hypothesis 3 is proposed: the nature of state-owned property rights negatively moderates the effect of third-party certification on green bond spread.

\section{Research design}

\subsection{Sample selection}

Green bonds issued in China from 2016 to 2019 were taken as research subjects. For data stability, the green bonds with unobvious attributes (such as green asset-backed securities), insufficient information disclosure (such as

ISSN: 0010-8189

(c) CONVERTER 2020

www.converter-magazine.info 
private bonds, etc.) and missing certain variables were removed and then 285 bond samples were obtained, types of which include financial bonds, corporate bonds, corporate bonds and medium-term notes. Among issuers of the green bond samples, state-owned enterprises accounted for $77.19 \%$, and non-state-owned enterprises accounted for $22.81 \%$. Among the state-owned issuers of the green bond samples are enterprises, central enterprises accounted for $23.64 \%$, and local enterprises accounted for $76.36 \%$.

\subsection{Variable definition}

Green bond spread was determined as the dependent variable by the green bond coupon rate minus the risk-free interest rate ${ }^{[6]}$. The risk-free interest rate was the comparable bond yield of treasury bond with the same maturity as the green bond on the day the green bond is issued. And the risk-free interest rate was calculated by linear interpolation with reference to the adjacent treasury bond yield, if there was no comparable treasury bond. Treasury bond yield data was taken from the China Central Depository and Clearing Corporation.

The third-party certification ( $\mathrm{Cer}$ ) was taken as dependent variable, a dummy variable. If the green bond was with third-party certification, the value was 1 , otherwise it was 0 . The certification information was found in China Financial Information Network.

The nature of property rights (Soe) was taken as a moderating variable. The value for central enterprises was 2 , for local enterprises was 1 , and for the others was 0 .

Factors that influence on cost of bonds include the macroeconomic conditions ${ }^{[8]}$, the bond characteristics and issuer characteristics $^{[9]}$. Common indicators of bond characteristics are mainly related to debt credit rating ${ }^{[10]}$, issue amount and bond maturity ${ }^{[11]}$. Common indicators of issuer characteristics are mainly related to issuers' industry ${ }^{[8]}$, the nature of property rights ${ }^{[12]}$, financial situation ${ }^{[13]}$, etc. Since, in the model, the year-fixed-effects involved the impact of macroeconomic conditions on bond interest rates, the factors as control variables were selected from two aspects: the bond characteristics and the issuer characteristics. In terms of the bond characteristics, issue amount (Amount), maturity (Dur), and bond credit rating are selected. In terms of issuer characteristics, firstly, since issuers of green bonds belong to the green industry, the specific industry where the issuers are located was not classified.

Hence, the representative indicators that different types of issuers pay attention to and disclose including return on equity, debt to asset ratio, the growth rate of equity, the growth rate of total assets and the growth rate of net profit, which are used to reflect financial status, were initially selected. Then, given that investors have learned the relevant data information of the financial status of the bond issuers when evaluating the bond credit spread, the financial indicators were all delayed by a period of data processing to avoid the endogenous problem of the model. In addition, since the financial indicators published by each issuer in each year were contingent to a certain degree, the indicators were smoothed by taking the annual average. Finally, in order to avoid redundancy in financial indicators, considering that the green bond samples were issued in 2016-2019, a short span resulting in little data, gray relational analysis was used to filter out key indicators among the above five indicators, because gray relational analysis has advantages in analyzing multiple factors in the system and judging the impact of each factor in the conditions of little data and poor information.

\subsection{The second synthetic degree of grey relational analysis}

The second synthetic degree of grey relation is composed of the absolute degree of grey relation and Deng's degree of grey relation ${ }^{[14]}$. Absolute degree of grey relation focuses on integral (relatively comprehensive) perspective while Deng's degree of grey relation focuses on grey incidence coefficient of certain points. Hence, the second synthetic degree of grey relation considers overall intimacy between two levels of an integral position and sequences ${ }^{[15]}$. The computation of the second synthetic degree of grey relation can be conducted as follow.

ISSN: 0010-8189

(c) CONVERTER 2020

www.converter-magazine.info 
Step 1: Determine data sequences:

Non-negative increasing sequences of the same length are assumed as:

$$
X_{i}=\left(x_{i}(1), x_{i}(2), \ldots, x_{i}(n)\right), i=0,1,2, \ldots
$$

where $X_{0}$ is the behavioral sequence and the others are relevant factor sequences.

Step 2: Calculate the absolute degree of grey relation:

Calculate the zero-starting point images of sequences, where:

$$
X_{i}^{0}=X_{i}-x_{i}(1)=\left(x_{i}(1)-x_{i}(1), x_{i}(2)-x_{i}(1), \ldots, x_{i}(n)-x_{i}(1)\right), i=0,1,2, \ldots
$$

And calculate $\left|s_{0}\right|,\left|s_{i}\right|$ and $\left|s_{0}-s_{i}\right|$ :

$$
\begin{gathered}
\left|s_{0}\right|=\left|\sum_{k=2}^{n-1} x_{0}^{0}(k)+\frac{1}{2} x_{0}^{0}(n)\right| \\
\left|s_{i}\right|=\left|\sum_{k=2}^{n-1} x_{i}^{0}(k)+\frac{1}{2} x_{i}^{0}(n)\right|, i=1,2,3 \ldots \\
\left|s_{0}-s_{i}\right|=\left|\sum_{k=2}^{n-1}\left(x_{0}^{0}(k)-x_{i}^{0}(k)\right)+\frac{1}{2}\left(x_{0}^{0}(n)-x_{i}^{0}(n)\right)\right|, i=1,2,3, \ldots
\end{gathered}
$$

Then, estimate the absolute degree of grey relation:

$$
\varepsilon_{0 i}=\frac{1+\left|s_{0}\right|+\left|s_{i}\right|}{1+\left|s_{0}\right|+\left|s_{i}\right|+\left|s_{0}-s_{i}\right|}, i=1,2,3, \ldots
$$

Step 3: Calculate Deng's degree of grey relation:

Calculate the initial images of sequences, where:

$$
X_{i}^{\prime}=\frac{x_{i}}{x_{i}(1)}=\left(\frac{x_{i}(1)}{x_{i}(1)}, \frac{x_{i}(2)}{x_{i}(1)}, \ldots, \frac{x_{i}(n)}{x_{i}(1)}\right), i=1,2,3, \ldots
$$

Calculate the incidence coefficients, and denote as:

$$
\gamma\left(x_{0}^{\prime}(k), x_{i}^{\prime}(k)\right)=\frac{\min _{i} \min _{k}\left|x_{0}^{\prime}(k)-x_{i}^{\prime}(k)\right|+\xi \max _{i} \max _{k}\left|x_{0}^{\prime}(k)-x_{i}^{\prime}(k)\right|}{\left|x_{0}^{\prime}(k)-x_{i}^{\prime}(k)\right|+\xi \max _{i} \max _{k}\left|x_{0}^{\prime}(k)-x_{i}^{\prime}(k)\right|}, \xi \subset(0,1), i=1,2,3, \ldots
$$

where $\left|x_{0}^{\prime}(k)-x_{i}^{\prime}(k)\right|$ is the difference of sequence $x_{0}^{\prime}(k)$ and $x_{i}^{\prime}(k), \max _{i} \max _{k}\left|x_{0}^{\prime}(k)-x_{i}^{\prime}(k)\right|$ is maximum differences, $\min _{i} \min _{k}\left|x_{0}^{\prime}(k)-x_{i}^{\prime}(k)\right|$ is minimum differences and coefficient.

Then, Deng's degree of grey relation can be estimated:

$$
\gamma\left(x_{0}^{\prime}, x_{i}^{\prime}\right)=\frac{1}{n} \sum_{k=1}^{n} \gamma\left(x_{0}^{\prime}(k), x_{i}^{\prime}(k)\right), i=1,2,3, \ldots
$$

Step 4: Calculate the second synthetic degree of grey relation written as $\rho_{0 \mathrm{i}}$ :

$$
\rho_{0 \mathrm{i}}=\theta \varepsilon_{0 i}+(1-\theta) \gamma_{0 i} ; \theta \in[0,1] ; i=1,2,3, \ldots
$$

ISSN: 0010-8189

(c) CONVERTER 2020 
where $\varepsilon_{0 i}$ is the absolute degree of grey relation, $\gamma_{0 i}$ is Deng's degree of grey relation, and $\theta$ represents the degree of support for the absolute degree of grey relation. To taking advantage of the two relation degrees, usually $\theta$ is 0.5 without being biased towards either terms.

According to the above formula and the data obtained, the behavioral sequence was composed of green bond spread, the relevant factor sequences were composed of financial indicators, and the degree of grey relation is shown in Table 1. The financial indicators were all sourced from the iFinD database of RoyalFlush.

Table 1 The grey relation degree between financial indicators and green bond spread.

\begin{tabular}{c|c|c|c|c|c}
\hline & $\begin{array}{c}\text { Return on } \\
\text { Equity }\end{array}$ & $\begin{array}{c}\text { Debt to } \\
\text { Asset Ratio }\end{array}$ & $\begin{array}{c}\text { the Growth } \\
\text { Rate of Equity }\end{array}$ & $\begin{array}{c}\text { the Growth Rate } \\
\text { of Total Assets }\end{array}$ & $\begin{array}{c}\text { the Growth Rate } \\
\text { of Net Profit }\end{array}$ \\
\hline $\begin{array}{c}\text { Absolute Degree of Grey } \\
\text { Relation }\end{array}$ & 0.6693 & 0.6406 & 0.6041 & 0.5285 & 0.5267 \\
\hline $\begin{array}{c}\text { Deng's Degree of Grey } \\
\text { Relation }\end{array}$ & 0.9715 & 0.9785 & 0.9748 & 0.5157 & 0.9681 \\
\hline $\begin{array}{c}\text { the Second Synthetic } \\
\text { Degree of Grey Relation }\end{array}$ & 0.8204 & 0.8095 & 0.7895 & 0.5221 & 0.7474 \\
\hline
\end{tabular}

As can be seen from Table 1, according to the second synthetic degree of grey relation, green bond spread indicates a strong association with return on equity by obtaining the highest weight (0.8204) followed by debt to assets ratio, the growth rate of equity, the growth rate of net profit and the growth rate of total assets by obtaining weights (0.8095), (0.7895), (0.7474) and (0.5221) respectively. In order to strengthen the relation between green bond spread and financial indicators and simplify the models, two financial indicators (return on equity and debt to assets ratio) with the second synthetic degree of grey relation greater than 0.8 were selected as control variables in terms of issuer characteristics.

In summary, the relevant variables are described in detail in Table 2.

Table 2 Variable description.

\begin{tabular}{|c|c|c|c|}
\hline Type & Name & Identification & Explanation \\
\hline $\begin{array}{l}\text { Independent } \\
\text { Variable }\end{array}$ & Green Bond Spread & Spread & $\begin{array}{l}\text { Green bond coupon rate minus comparable treasury } \\
\text { bond yields over the same period. Unit: } \%\end{array}$ \\
\hline $\begin{array}{l}\text { Dependent } \\
\text { Variable }\end{array}$ & $\begin{array}{l}\text { The Third-Party } \\
\text { Certification }\end{array}$ & Cer & $\begin{array}{l}\text { Dummy variable: } 1 \text { for with third-party certification } \\
\text { and } 0 \text { for without third-party certification. }\end{array}$ \\
\hline $\begin{array}{l}\text { Moderating } \\
\text { Variable }\end{array}$ & $\begin{array}{l}\text { The Nature of } \\
\text { Property Rights }\end{array}$ & Soe & $\begin{array}{l}\text { Points awarded: } 2 \text { to central enterprises assign; } 1 \text { to } \\
\text { local enterprises and } 0 \text { to the others. }\end{array}$ \\
\hline \multirow{5}{*}{$\begin{array}{c}\text { Control } \\
\text { Variables }\end{array}$} & Issue Amount & Amount & Unit: 100 million RMB. \\
\hline & Bond Maturity & Dur & Unit: year. \\
\hline & Bond Credit Rating & Rate & $\begin{array}{l}\text { Points awarded: } 5 \text { to } \mathrm{AAA}, 4 \text { to } \mathrm{AA}^{+}, 3 \text { to } \mathrm{AA}, 2 \text { to } \mathrm{AA}^{-} \text {, } \\
1 \text { to } \mathrm{A}^{+} \text {. }\end{array}$ \\
\hline & Return on Equity & Roe & $\begin{array}{l}\text { One year lagging data: net profit after tax divided by } \\
\text { equity. Unit: } \% \text {. }\end{array}$ \\
\hline & Debt to Assets Ratio & Lev & $\begin{array}{l}\text { One year lagging data: total liabilities divided by final } \\
\text { total assets. Unit: } \% \text {. }\end{array}$ \\
\hline
\end{tabular}

\subsection{Modeling}

ISSN: 0010-8189

(c) CONVERTER 2020

www.converter-magazine.info 
Based on the above analysis and variable definitions, it was assumed that the green bond market implements non-differentiated management, that was, the review and access conditions for different types of green bonds were the same. In addition, considering that the macroeconomic environment in different years have different effects on bond spread, the year-fixed-effect model was used. Models are constructed as follows.

Model 1: to examine the impact of third-party certification (Cer) on green bond spread, Model 1 was built as:

$$
\text { Spread }=\alpha_{0}+\beta_{1} \text { Cer }+\beta_{2} \text { Amount }+\beta_{3} \text { Dur }+\beta_{4} \text { Rate }+\beta_{5} \text { Roe }+\beta_{6} L e v+\text { Year }
$$

Model 2: the nature of property rights (Soe) was added to Model 1 to study the impact the nature of property rights on green bond spread and Model 2 was built as:

$$
\begin{aligned}
\text { Spread } & =\alpha_{0}+\beta_{1} \text { Cer }+\beta_{7} \text { Soe }+\beta_{2} \text { Amount }+\beta_{3} \text { Dur }+\beta_{4} \text { Rate }+\beta_{5} \text { Roe }+\beta_{6} \text { Lev } \\
& + \text { Year }
\end{aligned}
$$

Model 3: taken the nature of property rights as a moderating variable, the cross-product term (Soe_cer) of the nature of property rights and third-party certification was added to Model 2 in order to examine the impact of the nature of property rights on the effect of third-party certification and green bond spread, and Model 3 was built as:

$$
\begin{aligned}
\text { Spread } & =\alpha_{0}+\beta_{1} \text { Cer }+\beta_{7} \text { Soe }+\beta_{8} \text { Soe_cer }+\beta_{2} \text { Amount }+\beta_{3} \text { Dur }+\beta_{4} \text { Rate } \\
& +\beta_{5} \text { Roe }+\beta_{6} \text { Lev }+ \text { Year }
\end{aligned}
$$

Model 1 aimed to verify Hypothesis 1, Model 2 aimed to verify Hypothesis 2 and Model 3 aimed to verify Hypothesis 3. The variable symbols of the models are also listed in Table 2.

\section{Empirical analysis and results}

\subsection{Descriptive statistics}

\subsubsection{Descriptive statistics of the main variables}

In order to analyze the basic characteristics of the sample data, descriptive statistics of main variables were conducted. The results are shown in Table 3

Table 3 Descriptive statistics results.

\begin{tabular}{c|c|c|c|c}
\hline Variables & Mean & Std. Dev & Minimum & Maximum \\
\hline Spread & 1.691 & 0.984 & 0.372 & 4.961 \\
\hline Cer & 0.589 & 0.493 & 0 & 1 \\
\hline Soe & 0.954 & 0.640 & 0 & 2 \\
\hline Dur & 5.011 & 2.616 & 1 & 300.000 \\
\hline Amount & 19.554 & 36.419 & 1.000 & 5 \\
\hline Rate & 4.004 & 1.232 & 1 & 25.405 \\
\hline Roe & 7.634 & 5.837 & 25.616 & 94.607 \\
\hline Lev & 70.557 & 18.077 & -6.966 & \\
\hline
\end{tabular}

As can be seen from Table 3, the mean value of green bond issuance spread (Spread) is 1.69, and the distribution range is $[0.372,4.961]$, indicating that the green bond rate is generally higher than the risk-free rate and green bond spreads vary widely. The mean value of green bonds with the third-party certification $(\mathrm{Cer})$ is 0.589 , indicating

ISSN: 0010-8189

(C) CONVERTER 2020 
Volume 2021, No. 4

that overall, the proportion of green bonds with third-party certification in China does not exceed $60 \%$, and there is room for improvement in the popularity of third-party certification. The mean value of the nature of property rights (Soe) is 0.954 , which is close to 1 . It is because of the rules for assigning property rights: 0 for non-state-owned enterprises, 1 for local enterprises, and 2 for central enterprises, in the entire sample, the proportion of state-owned enterprises is $77.19 \%$, and among state-owned enterprises, central enterprises account for $23.64 \%$, relatively low. The average duration (Dur) is 5.011 years, indicating that green bond issuers generally raise medium to long-term funds, since the investment return period of green projects is long, and the green industry requires long-term funds to maintain projects. The distribution range of the issue amount (Amount) is [1.000, 300.000], with a mean value of 19.554, which is close to the left end of the distribution interval, indicating that in the samples, the bonds with little issue amount account for a high proportion. The mean value of the credit rating (Rate) is 4.004, indicating that green bonds are given relatively high credit rating in China. The standard deviation of the return on equity (Roe) is 5.837 , with a distribution ranging in $[-6.966,25.405]$, indicating that the profitability of green bond issuers in China is discrepant. The distribution range of the debt to assets ratio ( Lev) is [25.616, 94.607], with a mean value of 70.557, which is close to the right end of the distribution interval, indicating that the issuers are all operating in debt and there is a high proportion of issuers with a relatively high debt to assets ratio.

\subsubsection{Grouping descriptive statistics and testing of dependent variable}

Regardless of the classification of the nature of property rights, the spreads were grouped by third-party certification for descriptive statistics, and then the Independent-Sample T Test was done. The results are shown in Table 4.

Table 4 Analysis of the difference in green bond spread grouped by third-party certification.

\begin{tabular}{c|c|c|c}
\hline & $\begin{array}{c}\text { With third-party certification } \\
(\mathrm{N}=168)\end{array}$ & $\begin{array}{c}\text { Without third-party certification } \\
(\mathrm{N}=117)\end{array}$ & Difference \\
\hline Spread Mean & 1.388 & 2.124 & $-0.736^{* * *}$ \\
\hline
\end{tabular}

Notes: ${ }^{* * *}$ indicates significance level of 0.01 , and $\mathrm{N}$ is the number of the enterprises.

As can be seen from Table 4, the mean value of green bond spread with third-party certified (1.388) is significantly lower than that of green bond spread without third-party certified (2.124), indicating that third-party certification can reduce green bond spread. In this case, Hypothesis $\mathbf{1}$ is initially verified.

Regardless of whether the green bonds were with third-party certification, the spreads of central enterprises, local enterprises and non-state-owned enterprises were grouped and Independent-Sample T Test was done. The results are shown in Table 5.

Table 5 Analysis of differences in green bond spread grouped by the nature of property rights.

\begin{tabular}{c|c|c|c|c|c|c}
\hline Group & \multicolumn{2}{|c|}{$(1)$} & \multicolumn{2}{c|}{$(2)$} & \multicolumn{2}{c}{ (3) } \\
\hline $\begin{array}{c}\text { Enterprise } \\
\text { Types }\end{array}$ & $\begin{array}{c}\text { Central } \\
\text { Enterprise } \\
(\mathrm{N}=52)\end{array}$ & $\begin{array}{c}\text { Local } \\
\text { Enterprise } \\
(\mathrm{N}=168)\end{array}$ & $\begin{array}{c}\text { Central } \\
\text { enterprise } \\
(\mathrm{N}=52)\end{array}$ & $\begin{array}{c}\text { Non-State } \\
\text { Owned } \\
\text { Enterprise } \\
(\mathrm{N}=65)\end{array}$ & $\begin{array}{c}\text { Local } \\
\text { Enterprise } \\
(\mathrm{N}=168)\end{array}$ & $\begin{array}{c}\text { Non-State- } \\
\text { Owned } \\
\text { Enterprise } \\
(\mathrm{N}=65)\end{array}$ \\
\hline Spread mean & 1.228 & 1.819 & 1.228 & 1.728 & 1.819 & 1.728 \\
\hline \multicolumn{2}{|c|}{$-0.591^{* * *}$} & \multicolumn{2}{c|}{$-0.500^{* * *}$} & \multicolumn{2}{c}{0.091} \\
\hline
\end{tabular}

Notes: ${ }^{* * * *}$ indicates significance level of 0.01 , and $\mathrm{N}$ is the number of the enterprises.

As can be seen from Table 5, the mean value of central enterprises' green bond spread (1.228) is significantly lower than both local enterprises' green bond spread (1.819) and non-state-owned enterprises' green bond spread (1.728). The mean value of local enterprises' green bond spread is greater than that of non-state-owned enterprises'

ISSN: 0010-8189

(c) CONVERTER 2020

www.converter-magazine.info 
green bond spread, but the difference is not significant. In this case, although both central enterprises and local enterprises belong to state-owned enterprises, only the state-owned property rights of the central enterprises can reduce green bond spread, and that of local enterprises cannot. Hence, Hypothesis $\mathbf{2}$ is initially rejected.

However, although the difference in the mean value of one group is not significant, there are significant differences in the mean value of the others. Hence, it is reasonable to divide the property rights into three categories with the need to examine the impact of the nature of property rights on the effect of third-party certification on green bond spread.

With the classification of the nature of property rights where enterprises are divided into state-owned enterprises and non- state-owned enterprises and state-owned enterprises are divided into central enterprises and local enterprises, the spreads were grouped by third-party certification for descriptive statistics, and then the Independent-Sample T Test was done. The results are shown in Table 6.

Table 6 Analysis of differences in green bond spread grouped by third-party certification and the nature of property rights.

\begin{tabular}{|c|c|c|c|c|}
\hline & Enterprise Type & The Third-Party Certification & $\begin{array}{l}\text { Spread } \\
\text { Mean }\end{array}$ & Difference \\
\hline \multirow{4}{*}{$\begin{array}{l}\text { State-Owned Enterprise } \\
(\mathrm{N}=220, \mathrm{R}=77.19 \%)\end{array}$} & \multirow{2}{*}{$\begin{array}{l}\text { Central Enterprise } \\
(\mathrm{N}=52, \mathrm{R}=23.64 \%)\end{array}$} & Yes $(\mathrm{N}=32, \mathrm{R}=61.54 \%)$ & 1.098 & \multirow{2}{*}{$-0.339^{*}$} \\
\hline & & $\mathrm{No}(\mathrm{N}=20, \mathrm{R}=38.46 \%)$ & 1.437 & \\
\hline & \multirow{2}{*}{$\begin{array}{c}\text { Local Enterprise } \\
(\mathrm{N}=168, \mathrm{R}=76.36 \%)\end{array}$} & $\operatorname{Yes}(\mathrm{N}=84, \mathrm{R}=50.00 \%)$ & 1.402 & \multirow{2}{*}{$-0.835^{* * *}$} \\
\hline & & $\mathrm{No}(\mathrm{N}=84, \mathrm{R}=50.00 \%)$ & 2.237 & \\
\hline \multirow{2}{*}{\multicolumn{2}{|c|}{$\begin{array}{l}\text { Non-State-Owned Enterprise } \\
\quad(\mathrm{N}=65, \mathrm{R}=22.81 \%)\end{array}$}} & Yes $(\mathrm{N}=52, \mathrm{R}=80.00 \%)$ & 1.545 & \multirow{2}{*}{$-0.912^{* * * *}$} \\
\hline & & $\mathrm{No}(\mathrm{N}=13, \mathrm{R}=20.00 \%)$ & 2.457 & \\
\hline
\end{tabular}

Notes: ${ }^{*}$ and ${ }^{* * *}$ indicate significance level of 0.05 and 0.01 , respectively. $\mathrm{N}$ is the number of the enterprises. $\mathrm{R}$ is the proportion.

As can be seen from Table 6, among the green bond issuers, state-owned enterprises account for $77.19 \%$, of which, central enterprises account for $23.64 \%$, local enterprises account for $76.36 \%$, and non-state-owned enterprises account for $22.81 \%$. Among the green bonds issued by central enterprises, $61.54 \%$ are with third-party certification, among the green bonds issued by local enterprises, $50.00 \%$ are with third-party certification and among the green bonds issued by non-state-owned enterprises, $80.00 \%$ are with third-party certification. It is indicated that among green bond issuers, there are more state-owned enterprises than non-state-owned enterprises and among state-owned enterprises, there are more local enterprises than central enterprises, but there are more non-state-owned enterprises willing to take third-party certification than state-owned enterprises. Meanwhile, as can be seen from Table 6, among the green bonds issued by central enterprises, the spread mean with third-party certification is lower than that without third-party certification with difference of -0.339 at the significance level of 0.1 , among the green bonds issued by local enterprises, the spread mean with third-party certification is lower than that without third-party certification with difference of -0.835 at the significance level of 0.01 , and among the green bonds issued by the non-state-owned enterprises, the spread mean with third-party certification is lower than that without third-party certification with difference of -0.912 at the significance level of 0.01 . It is indicated that the average spread of green bond, no matter what type the issuers belong to, is affected by third-party certification. Green bond spreads with third-party certification are significantly lower than those without. Relatively speaking, the effect of third-party certification in reducing green bond spread is the greatest among non-state-owned enterprises, second among local enterprises, and slightest among central enterprises. In this case, Hypothesis 3 is initially verified.

\subsection{Correlation test}

ISSN: 0010-8189

(c) CONVERTER 2020

www.converter-magazine.info 
Spearman correlation test was performed on the main variables, using Stata 14.0. The results are shown in Table 7.

Table 7 Correlation coefficients of main variables.

\begin{tabular}{c|c|c|c|c|c|c|c|c}
\hline & Spread & Cer & Soe & Dur & Amount & Rate & Roe & Lev \\
\hline Spread & 1.000 & & & & & & & \\
\hline Cer & $-0.323^{* * * *}$ & 1.000 & & & & & & \\
\hline Soe & $-0.166^{* * *}$ & $-0.142^{* * *}$ & 1.000 & & & & & \\
\hline Dur & $0.166^{* * *}$ & $-0.473^{* * *}$ & $0.197^{* * *}$ & 1.000 & & & & \\
\hline Amount & $-0.436^{* * * *}$ & -0.050 & 0.077 & 0.013 & 1.000 & & & \\
\hline Rate & $-0.555^{* * *}$ & 0.065 & $0.261^{* * *}$ & -0.060 & $0.526^{* * *}$ & 1.000 & & \\
\hline Roe & $-0.186^{* * *}$ & $0.321^{* * *}$ & $-0.302^{* * *}$ & $-0.412^{* * *}$ & 0.025 & 0.043 & 1.000 & \\
\hline Lev & $-0.256^{* * *}$ & $0.408^{* * *}$ & $-0.318^{* * *}$ & $-0.487^{* * *}$ & $0.140^{* *}$ & 0.081 & $0.497^{* * *}$ & 1.000 \\
\hline
\end{tabular}

Notes: ${ }^{*},{ }^{* *}$ and ${ }^{* * *}$ indicate the significance level of $0.1,0.05$ and 0.01 , respectively.

As can be seen from Table 7, green bond spread (Spread) has the following relationship with other variables: First, it is negatively correlated with third-party certification (Cer) with correlation coefficient of -0.323 at the significance level of 0.01 , indicating that green bonds with third-party certification are with lower financing cost. Second, the correlation coefficient of the nature of property rights (Soe) is -0.166 at the significance level of 0.01 , indicating that the financing cost of the green bonds issued by state-owned enterprises is lower. Third, it has a significant positive correlation with bond maturity (Dur), indicating that the longer the maturity is, the larger green bond spread is, which is consistent with the liquidity premium theory in the bond term structure theory stating the longer the maturity of the bond is, the higher the bond risk premium is required by investors. Fourth, it has a significant negative correlation with issue amount (Amount), credit rating (Rate), return on equity (Roe) and debt to assets ratio $(L e v)$, indicating that within a certain range, the stronger liquidity of bonds is, the lower the default risk is, the stronger the issuer's profitability is, and the higher the market confidence in issuers' solvency is, the lower green bond spread is, which means there is lower financing costs.

In addition, since Model 3 introduces the cross-product term of third-party certification and the nature of property rights, in order to prevent the addition of cross-products term causing multicollinearity problems and improve the interpretation of the regression result coefficients, the cross-products term involved were implemented centralized processing, and VIF multicollinearity test was conducted to verify the effect of centralized processing. The results are shown in Table 8. As can be seen from Table 8, the maximum value of the variance expansion factor of each variable is 1.660 , which is much less than 10 , indicating there is not a suspicion multicollinearity in the model.

Table 8 VIF multicollinearity test.

\begin{tabular}{c|c|c|c|c|c|c|c|c}
\hline Variable & Cer & Soe & Soe_cer & Rate & Roe & Lev & Dur & Amount \\
\hline VIF & 1.350 & 1.330 & 1.120 & 1.200 & 1.520 & 1.660 & 1.320 & 1.150 \\
\hline 1/VIF & 0.742 & 0.751 & 0.891 & 0.833 & 0.659 & 0.602 & 0.760 & 0.866 \\
\hline Mean VIF & \multicolumn{10}{|c}{1.330} \\
\hline
\end{tabular}

\subsection{Regression analysis}

To avoid deviations in corporate data statistics leading to abnormal values of return on equity and debt to assets ratio, which in turn affects the empirical results, we carried out bilateral tailings on the $1 \%$ quantile of the above two variables. In addition, to avoid heteroscedasticity, we used robust standard errors to perform OLS regression after standardizing data. Moreover, considering that the macroeconomic environment in different years has different effects on bond spread, the year-fixed-effect model was used. The regression results are shown in Table 9.

ISSN: 0010-8189

(c) CONVERTER 2020 
Table 9 Regression result.

\begin{tabular}{|c|c|c|c|c|c|c|}
\hline & \multicolumn{2}{|c|}{ (1) } & \multicolumn{2}{|c|}{ (2) } & \multicolumn{2}{|c|}{ (3) } \\
\hline Variable & \multicolumn{2}{|c|}{ Spread } & \multicolumn{2}{|c|}{ Spread } & \multicolumn{2}{|c|}{ Spread } \\
\hline Cer & $-0.3355^{* * * x}$ & $(-5.63)$ & $-0.3356^{* * *}$ & $(-5.67)$ & $-0.3546^{* * * 1}$ & $(-5.75)$ \\
\hline Soe & & & $-0.0722^{*}$ & $(-1.67)$ & $-0.0879^{*}$ & $(-1.93)$ \\
\hline Soe_cer & & & & & $0.1681^{*}$ & (1.83) \\
\hline Dur & -0.0642 & $(-1.54)$ & -0.0673 & $(-1.62)$ & $-0.0739^{*}$ & $(-1.81)$ \\
\hline Amount & $-0.0226^{* *}$ & $(-2.57)$ & $-0.0210^{* * *}$ & $(-2.35)$ & $-0.0218^{* * *}$ & $(-2.47)$ \\
\hline Rate & $-0.2382^{* * * *}$ & $(-9.59)$ & $-0.2272^{* * * *}$ & $(-8.81)$ & $-0.2280^{* * * * 3}$ & $(-8.78)$ \\
\hline Roe & -0.0168 & $(-0.43)$ & -0.0304 & $(-0.79)$ & -0.0288 & $(-0.75)$ \\
\hline Lev & $-0.2807^{* *}$ & $(-2.18)$ & $-0.3274^{* * *}$ & $(-2.44)$ & $-0.2919^{* *}$ & $(-2.12)$ \\
\hline _cons & $2.3054^{* * * *}$ & $(12.09)$ & $2.3967^{* * * *}$ & $(11.72)$ & $2.4060^{* * * *}$ & $(11.73)$ \\
\hline Fixed-Effect & \multicolumn{2}{|c|}{ Yes } & \multicolumn{2}{|c|}{ Yes } & \multicolumn{2}{|c|}{ Yes } \\
\hline Sample Size & \multicolumn{2}{|c|}{285} & \multicolumn{2}{|c|}{285} & \multicolumn{2}{|c|}{285} \\
\hline $\mathrm{R}^{2}$ & \multicolumn{2}{|c|}{0.5105} & \multicolumn{2}{|c|}{0.5154} & \multicolumn{2}{|c|}{0.5219} \\
\hline Adj $R^{2}$ & \multicolumn{2}{|c|}{0.4945} & \multicolumn{2}{|c|}{0.4977} & \multicolumn{2}{|c|}{0.5027} \\
\hline $\mathrm{F}$ & \multicolumn{2}{|c|}{31.87} & \multicolumn{2}{|c|}{29.14} & \multicolumn{2}{|c|}{27.10} \\
\hline
\end{tabular}
T-value.

4.3.1 The impact of third-party certification on green bond spread

Column (1) of Table 9 demonstrates the regression results of Model 1. As can be seen, the F- value is 31.87, reaching the significance level of 0.01 . The coefficient of third-party certification $(C e r)$ is -0.3355 , which is significant at the level of 0.01 , indicating that third-party certification can significantly reduce green bond spread contributing to reducing financing costs for issuers. Hence, Hypothesis 1 is proved.

\subsubsection{The impact of the nature of property rights on green bond spread}

Column (2) of Table 9 demonstrates the regression results of Model 2. As can be seen, the F- value is 29.14, reaching the significance level of 0.01 . third-party certification is still significantly negatively correlated with green bond spread at the level of 0.01 (coefficient of -0.3356), which is consistent with Hypothesis 1 . In this case, the robustness of Hypothesis 1 is improved. In addition, the coefficient of the nature of property rights (Soe) is -0.0722 , which is significant at the 0.1 level. The absolute value of the coefficient of property rights is smaller than that of third-party certification, indicating that compared to third-party certification, the nature of property rights has slighter impact on green bond spread. Since central enterprises, local enterprises and non-state-owned enterprises were assigned values of 2, 1 and 0 respectively, the significantly negative coefficient of the nature of property rights indicates that the state-owned property can significantly reduce green bond spread and moreover, the nature of state-owned property rights in central enterprises, compared with that in local enterprises, has a greater effect in reducing green bond spread. Hence, Hypothesis 2 is proved.

4.3.3 The impact of the nature of property rights on the relationship between third-party certification and green bond spread

Column (3) of Table 9 demonstrates the regression results of Model 3. As can be seen, the F value is 27.10, reaching the significance level of 0.01 . The coefficient of the nature of property rights (Soe) is -0.0879 , and the coefficient of the cross-product term of third-party certification and the nature of property rights (Soe_cer) is 0.1681 , both of which are significant at the 0.1 level. In addition, according to the assignment rules for central enterprises, local enterprises and non-state-owned enterprises, the above indicates that the nature of state-owned property rights can significantly negatively moderate the effect of third-party certification on green bond spread, and furthermore, the negative moderation has a greater effect in central enterprises, compared in local enterprises.

ISSN: 0010-8189

(c) CONVERTER 2020 
Hence, Hypothesis 3 is proved.

\subsection{Robustness test}

To further verify the robustness of the previous conclusions, a 5\% bilateral tailing treatment on the return on equity and debt to assets ratio and robust standard error OLS regression on Model 1, Model 2, and Model 3 were conducted. The results are shown in Table 10. As can be seen from Table 10, the study conclusions are not denied.

Table 10 Robust test results.

\begin{tabular}{|c|c|c|c|c|c|c|}
\hline & \multicolumn{2}{|c|}{ (1) } & \multicolumn{2}{|c|}{ (2) } & \multicolumn{2}{|c|}{ (3) } \\
\hline Variable & \multicolumn{2}{|c|}{ Spread } & \multicolumn{2}{|c|}{ Spread } & \multicolumn{2}{|c|}{ Spread } \\
\hline $\mathrm{Cer}$ & $-0.3359^{* *}$ & $(-5.65)$ & $-0.3357^{* * * *}$ & $(-5.68)$ & $-0.3546^{* * * *}$ & $(-5.77)$ \\
\hline Soe & & & $-0.0742^{*}$ & $(-1.70)$ & $-0.0899^{*}$ & $(-1.95)$ \\
\hline Soe_cer & & & & & $0.1687^{*}$ & $(1.83)$ \\
\hline Dur & -0.0652 & $(-1.56)$ & $-0.0688^{*}$ & $(-1.65)$ & $-0.0756^{*}$ & $(-1.84)$ \\
\hline Amount & $-0.0222^{* *}$ & $(-2.52)$ & $-0.0203^{\text {** }}$ & $(-2.28)$ & $-0.0212^{* *}$ & $(-2.40)$ \\
\hline Rate & $-0.2396^{* *}$ & $(-9.65)$ & $-0.2284^{* * * *}$ & $(-8.87)$ & $-0.2292^{* * * *}$ & $(-8.83)$ \\
\hline Roe & -0.0189 & $(-0.48)$ & -0.0329 & $(-0.84)$ & -0.0317 & $(-0.82)$ \\
\hline Lev & $-0.2915^{* *}$ & $(-2.21)$ & $-0.3459^{* *}$ & $(-2.50)$ & $-0.3073^{* * *}$ & $(-2.16)$ \\
\hline _cons & $2.3262^{* * *}$ & (12.08) & $2.4274^{* * *}$ & (11.66) & $2.4337^{* * *}$ & (11.63) \\
\hline Fixed-Effect & \multicolumn{2}{|c|}{ Yes } & \multicolumn{2}{|c|}{ Yes } & \multicolumn{2}{|c|}{ Yes } \\
\hline Sample Size & \multicolumn{2}{|c|}{285} & \multicolumn{2}{|c|}{285} & \multicolumn{2}{|c|}{285} \\
\hline $\mathrm{R}^{2}$ & \multicolumn{2}{|c|}{0.5102} & \multicolumn{2}{|c|}{0.5153} & \multicolumn{2}{|c|}{0.5219} \\
\hline $\operatorname{Adj} R^{2}$ & \multicolumn{2}{|c|}{0.4942} & \multicolumn{2}{|c|}{0.4976} & \multicolumn{2}{|c|}{0.5027} \\
\hline $\mathrm{F}$ & \multicolumn{2}{|c|}{31.83} & \multicolumn{2}{|c|}{29.13} & \multicolumn{2}{|c|}{27.09} \\
\hline
\end{tabular}
T-value.

\section{Conclusions and recommendations}

\subsection{Conclusions}

The 285 green bonds issued in China from 2016 to 2019 were used as research objects to examine the impact of third-party certification on green bonds.

Descriptive statistics results indicate that first, the proportion of the green bonds issued with third-party certification is less than $60 \%$, second, nearly $80 \%$ of green bond issuers are state-owned enterprises and third, green bond issuers tend to raise medium to long-term funds because of green projects with a long investment return period.

The regression analysis results indicate that first, there is a significant reduction in green bond spread with third-party certification, second, state-owned enterprises' green bond spread is lower than non-state-owned enterprises' green bond spread and third, for non-state-owned enterprise issuers, third-party certification has a greater effect on reducing green bond issuance spread.

\subsection{Recommendations}

Based on the research conclusions, the suggestions are put forward.

ISSN: 0010-8189

(c) CONVERTER 2020 
Volume 2021, No. 4

First, it is as soon as possible that the certification standards for green bonds should be improved and the process of third-party certification should be standardized since during rapid growth of the green industry, green bond funds are required to support green projects and furthermore, the lower the fund cost is, the more benefits there are to the developing green industry. It is revealed that third-party certification can significantly reduce green bond spread, meaning that it can reduce the financing cost for the issuers in the green industry. From the perspective of reducing green bond financing costs, the issuers should be motivated to carry out third-party certification. However, descriptive statistics show that at present, less than $60 \%$ of green bonds issued are with third-party certification. There are many reasons for this undesirable phenomenon in the green bond market, among which poor certification standards for green bonds may matter most. The Green Bond Evaluation and Certification Behavior Guidelines (Interim) jointly issued by the Central Bank of the People's Republic of China and the China Securities Regulatory Commission in 2017 states that before green bonds issued, it is necessary to determine whether the green project screening and decision-making procedures are compliant and whether the environmental benefit target is reasonable, but without containing judging criteria of whether the program is compliant and whether the target is reasonable. As a result, different certification authorities have different understandings of compliance and reasonableness, leading to discrepancies in certification standards and certification results. Consequently, there are the certification results with low level of reliability and low level of credibility. Hence, detailed judging indicators of compliance, completeness and effective execution of information related to green bonds should be introduced as soon as possible to standardize and qualify third-party certification in order to encourage the issuers to be actively engaged in the certification.

Second, non-state-owned enterprises should make the most of third-party certification. It is revealed that green bonds with third-party certification are issued in a lower spread than those without. The phenomenon is more significant in non-state-owned enterprises than in state-owned enterprises. Hence, given the differences in the financing status of enterprises with different property rights in the green industry, when to issue green bonds, non-state-owned enterprises should be actively involved in taking third-party certification to disclose more information about the environmental and social benefits of green bonds to be issued, which can ease the "greenwashing" risk, contributing to lower financing cost of green bonds.

Third, the government should be in a better effort to implement third-party certification. On the one hand, an incentive mechanism for third-party certification can be established. For example, in the same conditions, a more convenient "green channel" can be provided for enterprises to issue green bonds with third-party certification. On the other hand, green bonds to be issued can be gradually compulsory to carry out third-party certification, which not only enables issuers to enjoy the benefits of lower financing costs, but also enhances the transparency of information of green bonds to ease the "greenwashing" risk, ensuring the quality of green bonds to be issued.

Forth, multi-party cooperation needs to be strengthened to reduce the risk of green bonds and public awareness of green bonds should be aroused. It is revealed that the green bond interest rate is much higher than the risk-free interest rate measured by the treasury bond yield (high premium). It mainly caused by the "greenwashing" risk. Hence, it is suggested that China Development Bank is supposed to build the green bond market together with various tiers of the governments and commercial banks to ease the "greenwashing" risk. In that case, green bond spread can be lower so that non-state-owned enterprises, such grassroots units, can obtain stronger financial support through issuing green bonds. In addition, education campaigns on green development, green finance, and green life should be actively conducted to arouse citizens' awareness of the role of green bonds, inspiring them to invest in green bonds.

\section{Acknowledgement}

[Fund Project] The Major Social Science Project of Tianjin Municipal Education Commission "Research on the Spatial Reconstruction and Optimization Mechanism of the Green Development Industrial Chain in Beijing,

ISSN: 0010-8189

(c) CONVERTER 2020

www.converter-magazine.info 
CONVERTER MAGAZINE

Volume 2021, No. 4

Tianjin and Hebei" (2018ZWZD16). The Project of the National Social Science Fund of China "Research on Green Development Evaluation and Planning System Based on Full Carbon Accounting" (18BJY079).

\section{References}

[1] Macaskill S, Roca E, Liu B et al. Is there a green premium in the Green Bond market? Systematic literature review revealing premium determinants. Journal of Cleaner Production, 2020 (280): 1-33

[2] Fatica S, Panzica R, Rancan M. The pricing of green bonds: are financial institutions special?. Mo.Fi.R. Working Papers, 2019 (54): 2-20

[3] Yun J, Won D K, Park K B et al. The role of a business model in market growth: The difference between the converted industry and the emerging industry. Technological Forecasting and Social Change, 2019 (146): 534-562

[4] Yang Andrew Wu, Artie W. Ng et al. A review of evolutionary policy incentives for sustainable development of electric vehicles in China: Strategic implications. Energy Policy, 2020 (148): 1-11

[5] Luo Q, Miao C, Sun L et al. Efficiency evaluation of green technology innovation of China's strategic emerging industries: An empirical analysis based on Malmquist-data envelopment analysis index. Journal of Cleaner Production, 2019 (238): 1-10

[6] Fang Hongxing, Shi Jikun, Zhang Guangbao. Property Rights, Information Quality and Corporate Bond Pricing__Empirical Evidence from China’s Capital Market. Financial Research, 2013 (4): 170-182.

[7] Chen Yinghui, Peng Chenchen, Chan Kam C. Earnings management uncertainty, implicit guarantees, and the corporate bond yield spread: Evidence from China. Borsa Istanbul Review, 2020 (11): 1-19

[8] Urbi Garay, Maximiliano González, John Rosso. Country and industry effects in corporate bond spreads in emerging markets. Journal of Business Research, 2017: 191-200

[9] Wulandari F, Schfer D et al. The impact of liquidity risk on the yield spread of green bonds. Finance Research Letters, 2018 (27): 53-59

[10] Kelly C N, Jean H, Arthur W. Underpricing in the Corporate Bond Market. Review of Financial Studies, 2007 (6): 2021-2046

[11] $\mathrm{Xu} \mathrm{S,} \mathrm{Gong} \mathrm{G,} \mathrm{Gong} \mathrm{X.} \mathrm{Accruals} \mathrm{quality,} \mathrm{underwriter} \mathrm{reputation,} \mathrm{and} \mathrm{corporate} \mathrm{bond} \mathrm{underpricing:}$ Evidence from China. China Journal of Accounting Research, 2017, 10 (4): 27-49

[12] Qinghua Wang, Yaning Zhou et al. Research on the Factors Affecting the Risk Premium of China's Green Bond Issuance. Sustainability, 2019, 11(22): 1-14

[13] Michael Minnis. The Value of Financial Statement Verification in Debt Financing: Evidence from Private U. S. Firms. Journal of Accounting Research, 2011, 49(2): 457-505

[14] S.A. Javed, S. Liu. Evaluation of outpatient satisfaction and service quality of Pakistani healthcareprojects: Application of a novel synthetic grey incidence analysis model. Grey Systems: Theory and Application, 2018: 462-480

[15] Ikram M, Sroufe R, Rehman E et al. Do Quality, Environmental, and Social (QES) Certifications Improve International Trade? A Comparative Grey Relation Analysis of Developing vs. Developed Countries. Physica A: Statistical Mechanics and its Applications, 2020, 545: 1-36

ISSN: 0010-8189

(c) CONVERTER 2020

www.converter-magazine.info 